\title{
Organic Agriculture makes People Healthier
}

\author{
Liyue Guo* \\ Institute of Botany, the Chinese Academy of Sciences, China
}

*Corresponding author: Liyue Guo, State Key Laboratory of Vegetation and Environmental Change, Institute of Botany, the Chinese Academy of Sciences, 20 Nanxincun, Xiangshan, Beijing 100093, China.

To Cite This Article: Liyue Guo, Organic Agriculture makes People Healthier. 2020 - 10(6). AJBSR.MS.ID.001573.

DOI: 10.34297/AJBSR.2020.10.001573.

Received: 眥 October 31, 2020; Published: 㭗 November 16, 2020

\section{Opinion}

Current agriculture is characterized by excessive inputs of chemical fertilizers, pesticides, herbicides, and hormones, while insufficient application of organic fertilizers. It has been proved to be effective to increase yields of crops, vegetables and fruits [1], however, it also has resulted in numerous negative effects on the environment, including water, soil and food pollution, degradation of soil quality [2]. The biodiversity of plant and microbe has also declined in current agricultural ecosystem [3]. More seriously, high eco-toxicity and synergistic toxicity materials remained in the foods which might enrich through food chain to threat human health [4]. Previous researches frequently found that the residues of herbicides and pesticides in foods seriously harmed human health, such as damaging the nervous system and inducing lung fibrosis [5].

According to the World Health Organization (WHO) and the United Nations Environment Programme (UNEP), 26 million people worldwide were poisoned by pesticides each year. The use of pesticides increases the incidence of various cancers and the risk of Parkinson disease [6]. Current agriculture pays too much attention to crop yield and taste, and neglects its nutritional performance, resulting in the decline of crop nutritional quality. It was found that the contents of 43 different fruits and vegetables decreased significantly in protein, Ca, P, Fe, Vitamin B and vitamin C from 1950 to 1999 [7]. The decline in crop nutrition quality has aggravated the problem of hidden hunger. Hidden hunger caused by the lack of trace elements threatens more than 2 billion people in the world, and the most vulnerable groups are women, children and the old men or women [8].

With the growing focus on food safety and environmental protection, people began to emphasize the important role of organic management of orchards or croplands. Compared with current agriculture, organic agriculture prohibits the use of chemical fertilizers, pesticides, herbicides, growth regulators and genetic engineering, while uses organic fertilizers to improve soil quality, uses ecological technologies to control pests and weeds. The herbicides and pesticides can be not found in the food and fruits which were produced in the organic agriculture, so both the farmers and consumers can be not poisoned by pesticides and herbicides. On the other hand, because of adding organic fertilizers in the soil, some trace elements can be supplemented in the soil, so the organic food are more nutritious [9]. Therefore, in my opinion, organic agriculture makes people healthier.

\section{Acknowledgement}

None.

\section{Conflict of Interest}

There is no conflict of interest.

\section{References}

1. Tilman D, Cassman KG, Matson PA, Rosamond Naylor, Stephen Polasky (2002) Agricultural sustainability and intensive production practices. Nature 418(6898): 671-677.

2. Guo LY, Wu GL, Li CH, Xiaofan Yu, Da Cheng, et al. (2015) Vermicomposting with maize increases agricultural benefits by 304\%. Agronomy for Sustainable Development 35(3): 1149-1155.

3. Yu C, Hu XM, Deng W, Y.Li, C Xiong, et al. (2015) Changes in soil microbial community structure and functional diversity in the rhizosphere surrounding mulberry subjected to long-term fertilization. Applied Soil Ecology 86: 30-40.

4. Laetz CA, Baldwin DH, Collier TK, Vincent Hebert, John D Stark, et al. (2009) The synergistic toxicity of pesticide mixtures: implications for risk assessment and the conservation of endangered pacific salmon. Environmental Health Perspectives 117(3): 348-353. 
5. Cen Y, Li LJ, Guo LY, CaihongLi, Gaoming Jiang (2020) Organic management enhances both ecological and economic profitability of apple orchard: a case study in Shandong Peninsula. Scientia Horticulturae 265: 109201.

6. van der Mark M, Brouwer M, Kromhout H, Peter Nijssen, Anke Huss, et al. (2012) Is pesticide use related to Parkinson disease? Some clues to heterogeneity in study results. Environmental Health Perspectives 120(3): 340-347

7. Davis DR, Epp MD, Riordan HD (2004) Changes in USDA food composition data for 43 garden crops, 1950 to 1999. Journal of the American College of Nutrition 23(6): 669-682.
8. Burchi F, Fanzo J, Frison E (2011) The role of food and nutrition system approaches in tackling hidden hunger. International Journal of Environmental Research and Public Health 8(2): 358-373.

9. Średnicka Tober D, Barański M, Seal CJ, Roy Sanderson, Charles Benbrook, et al. (2016) Higher PUFA and n3 PUFA, conjugated linoleic acid, $\alpha$-tocopherol and iron, but lower iodine and selenium concentrations in organic milk: a systematic literature review and meta and redundancy analyses. British Journal of Nutrition 115(6): 10431060. 